(c) American Dairy Science Association, 2003.

\title{
Effect of Pregnancy on Milk Production and Bodyweight from Identical Twin Study
}

\author{
J. R. Roche \\ Dexcel (formerly Dairying Research Corporation), Hamilton, New Zealand
}

\begin{abstract}
The energy requirements of the fetus through pregnancy have been previously investigated in several slaughter experiments, and many studies have attempted to estimate the effect of pregnancy on milk production. Data from 154 pasture-based dairy cows ( 77 twin pairs) were subjected to a retrospective analysis to determine the effect of pregnancy on milk production and body weight. A decline in milk yield from $126 \mathrm{~d}$ of pregnancy was observed in twins that were pregnant, but the decline was small and insignificant until $147 \mathrm{~d}$ of gestation (at $33 \mathrm{wk}$ of lactation), after which pregnant cows produced less milk $(0.8 \mathrm{~kg} / \mathrm{cow}$ per day). Protein and fat concentration increased in pregnant cows from 77 and $133 \mathrm{~d}$ of gestation, respectively. The yield of milk fat and protein was not affected by pregnancy until $168 \mathrm{~d}$ of gestation, after which pregnant cows produced less milk fat $(0.06 \mathrm{~kg} / \mathrm{cow}$ per day) and milk protein $(0.04 \mathrm{~kg} / \mathrm{cow}$ per day) compared with their nonpregnant twins. Body weight was higher in pregnant twin cows after $90 \mathrm{~d}$ of gestation and continued to increase until the end of lactation (182 d of pregnancy). Fitted splines showed higher milk protein concentrations in pregnant cows throughout lactation, and milk protein yield was higher ( $20 \mathrm{~g} / \mathrm{cow}$ per day) during the breeding season (between 12 to $17 \mathrm{wk}$ of lactation) in pregnant twins. Higher milk yield and energy secreted in milk (net energy for lactation) were also found in the pregnant twins during the breeding season. Although pregnancy-related reductions in yields of milk, milk fat, and milk protein occurred after midgestation, overall effects of pregnancy on milk production in this pasture-based, seasonal calving system were small.
\end{abstract}

Key words: milk production, pregnancy, pasture, reproduction

\section{INTRODUCTION}

Dairy cows are pregnant for much of their lactation in seasonal calving systems, and although the effect of

Received September 1, 2002.

Accepted November 27, 2002.

Corresponding author: J. Roche; e-mail: john.roche@dexcel.co.nz. days open on total milk production has been reported, few quantitative data are available to calculate the effect of pregnancy on milk production. Bell et al. (1995) defined the energy requirements of the pregnant dairy cow after $190 \mathrm{~d}$ of gestation. Holstein cows were serially slaughtered at various stages of gestation after $190 \mathrm{~d}$, and a quadratic equation was developed to describe the daily change in energy content of the gravid uterus. Energy requirements directly attributable to pregnancy are presumed to be close to zero (NRC, 2001), when the day of gestation is $<190 \mathrm{~d}$ ( $\sim 273 \mathrm{~d}$ of lactation in seasonal calving dairy herds in New Zealand). In most seasonal calving situations, a lactation length of $305 \mathrm{~d}$ is targeted, thereby allowing a 2-mo dry period. Therefore, the energy requirements of the gravid uterus would not be expected to have a significant effect on milk production.

However, Eley et al. (1978) and Prior and Laster (1979) reported an exponential growth of fetal tissues, with growth and, therefore, energy demand, increasing after $90 \mathrm{~d}$ pregnant. In support of this increased energy demand, Bormann et al. (2002) reported a decline in the yield of milk, milk fat, and milk protein, from approximately $90 \mathrm{~d}$ in pregnant cows, compared with nonpregnant cows. The difference in production was particularly noticeable during the third trimester of gestation. The report of Bormann et al. (2002) suggests that there is a milk production cost of pregnancy well in advance of $190 \mathrm{~d}$. However, the significance of the difference between milk yields of pregnant and nonpregnant cows was not reported.

Lee et al. (1997) showed a significant relationship between days open (i.e., pregnancy status) and 305-d milk yield, and their report showed that even a slight change in days open $(<10 \mathrm{~d})$ had significant effects on milk production. However, they also pointed out that days open alone is probably not an accurate means of assessing the effect of pregnancy, as there is a high probability that it is the higher-yielding cows that have greater days open, thereby biasing the result by up to $70 \%$. Having removed the effect of early lactation milk yield (first 100 d), Lee et al. (1997) still found that pregnant cows produced $265 \mathrm{~kg}$ less milk, $9.8 \mathrm{~kg}$ less fat, and $9.2 \mathrm{~kg}$ less protein than nonpregnant cows over $305 \mathrm{~d}$. 
Previous reports outlining the effect of pregnancy on milk production have been based on data from unrelated cows. This paper outlines the difference in milk production and cow BW in pairs of twin dairy cows, where one cow in each pair conceived and the other did not.

\section{MATERIALS AND METHODS}

The effect of pregnancy on milk production, milking speed, SCC, and BW was investigated using data from 154 dairy cows (77 twin pairs) between 1995 and 2001, where one twin was successfully mated and the other did not become pregnant. The cows were of mixed breed (Friesian, Jersey, and Friesian x Jersey) and were managed as part of an intensive rotational grazing system at No. 1 Dairy, Dexcel, Ltd. (formerly Dairying Research Corporation), Hamilton, New Zealand ( $37^{\circ} 46^{\prime} \mathrm{S} 175^{\circ}$ 18 E).

\section{Twin Cows}

The Dexcel herd of twin cows is a research resource that is maintained annually by acquiring identical twin calves from producers and rearing them together with other replacement stock. The twin herd is managed as one herd ( 150 cows, 75 twin pairs). In situations in which one cow of the twin pair becomes pregnant and its identical twin fails to conceive, they are milked through lactation, and then both twins are culled. Hence, actual data on calf birthweight and actual calving date from the pregnant twin was not available.

\section{Farm System}

Approximately $60 \%$ of the annual pasture production in New Zealand occurs between September and January (Macdonald, 1997). Appropriate matching of herd intake demand with pasture growth and a condensed seasonal calving period (6 to $8 \mathrm{wk}$ ) are used to make optimal use of the supply of pasture. The Dexcel twin herd were stocked at three cows/ha and had an average calving date of July 22 . To maintain a 365-d calving period, the breeding season, therefore, coincides with wk 12 to 17 of lactation for the majority of cows, and this period (wk 12 to 17) was defined as the breeding season for this study.

Cows were rotationally grazed as one herd. In this intensive grazing system, cows rotationally grazed approximately 30 paddocks of ryegrass-dominant pasture. Cows had access to a fresh allocation of pasture daily and only returned to the same area when a minimum of two leaves had appeared on the majority $(>75 \%)$ of perennial ryegrass tillers.

\section{Measurements}

After calving, cows were milked twice daily at 0730 and $1530 \mathrm{~h}$, and individual milk yields were recorded (Waikato milk meter system, New Zealand). Fat, protein, and lactose concentrations of milk were determined by FT-120 (Foss Electric, Hilleröd, Denmark) on individual p.m. and a.m. samples on $1 \mathrm{~d}$ each week. Cows were weighed weekly throughout the year.

\section{Statistical Analysis}

The time trends and interaction of time with pregnancy status were analyzed using smoothing spline methods as in Verbyla et al. (1999). Models were fitted using REML. These methods fit smooth, nonlinear curves to the data from the two groups, modeling the trends and the covariance structure of the repeated measurements simultaneously. The formulation of the cubic smoothing splines as linear mixed models enables differences between the two curves to be tested using likelihood ratio tests for the spline components and Wald tests for the linear components. The milk production, milking speed, SCC, and BW data for each week postcalving, and the mean values for each third of lactation ( 1 to 12,13 to 25 , and 26 to $38 \mathrm{wk}$ ) and the breeding period (wk 12 to 17) were then analyzed using ANOVA. All statistical analyses were carried out using the statistical software in Genstat (Genstat 6, 2002).

\section{RESULTS}

Over the entire lactation, there was no difference in milk yield, the yield of fat, protein, or lactose, or energy $\left(\mathrm{NE}_{\mathrm{L}}\right)$ expended in milk production between pregnant and nonpregnant dairy cows (Figure 1). Pregnant cows produced milk that had higher mean concentrations of protein $(0.05$ percentage units; $P<0.001)$ and lactose (0.02 percentage units; $P<0.05$ ) and produced more protein $(0.01 \mathrm{~kg} / \mathrm{cow}$ per day; $P=0.06)$ during the period of lactation that they were pregnant compared to the comparable period for their nonpregnant twins (Table 1).

Table 1 shows the mean daily milk production of the pregnant and nonpregnant twin cows during the three trimesters of lactation, during the period of lactation that the cows were pregnant, and during the breeding season. There was no difference in any of the measured milk production variables or BW during the first third of lactation (1 to $12 \mathrm{wk}$ ). During the second third of lactation (13 to $25 \mathrm{wk}$ ), there was a trend towards a 0.03 percentage unit increase $(P<0.1)$ in milk protein concentration in cows that became pregnant, and milk protein yield was $0.01 \mathrm{~kg} / \mathrm{cow}$ per day higher $(P<0.05)$ in pregnant cows. The means of the other production 

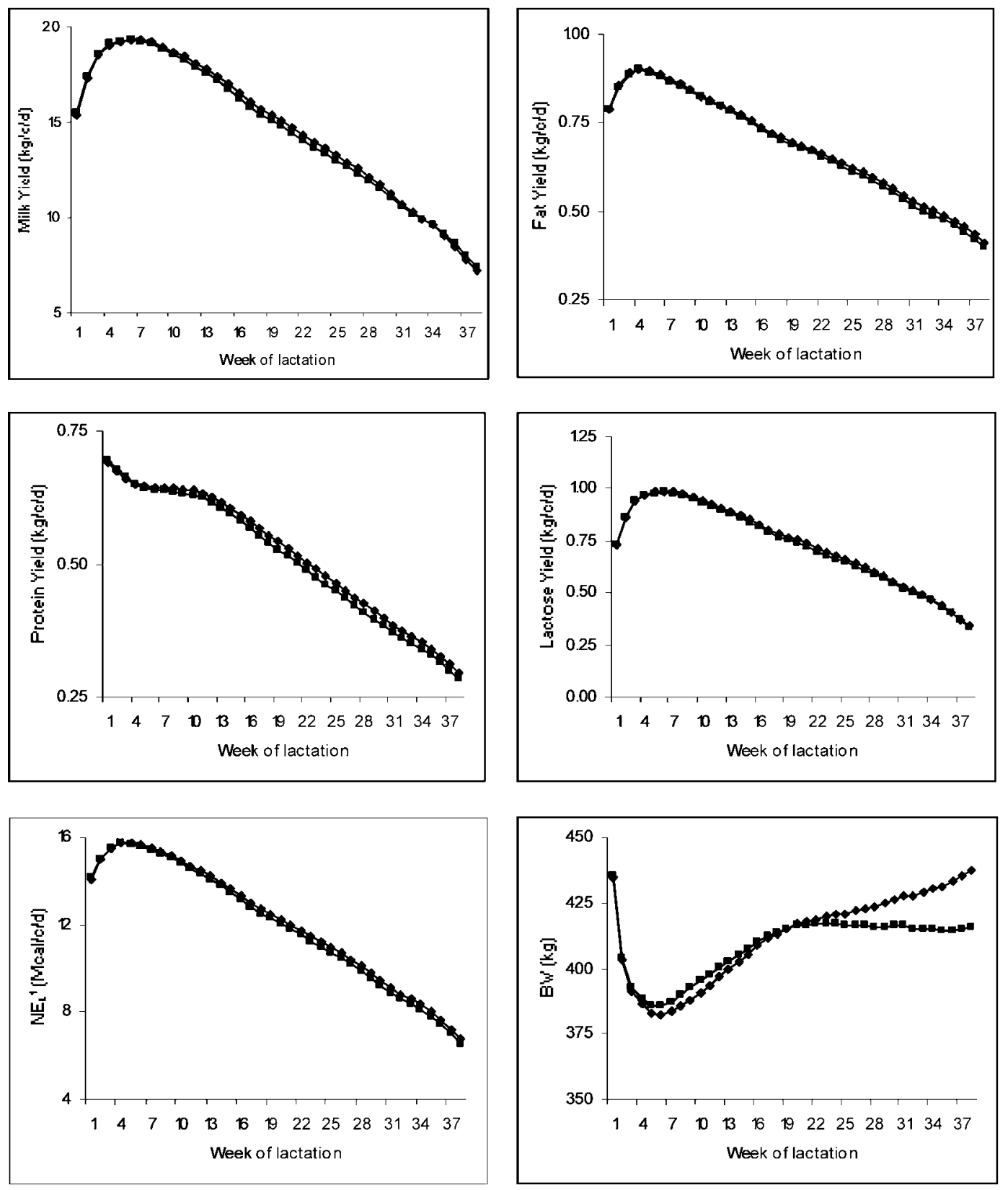

Figure 1.Fitted splines showing the interaction between pregnancy status and stage of gestation in milk yield, milk component yield, energy content of milk and BW of pregnant $\left(\right.$ ) and nonpregnant $(\mathbf{\square})$ twin cows throughout lactation. ${ }^{1} \mathrm{NE}_{\mathrm{L}}=0.0929 \times \mathrm{Fat} \%+0.0547 \times$ $\mathrm{CP} \%+0.0395 \times$ Lactose $\%(\mathrm{NRC}, 2001)$

variables (milk, fat, and lactose yield, and BW) were not affected by pregnancy status during the second third of lactation.

Although BW began to increase $(P<0.05)$ in pregnant cows after 25 wk of lactation, mean milk production values were not different across the entire final third of lactation. The negative effect of pregnancy on milk production became apparent late in lactation, with reduced milk yield $(0.8 \mathrm{~kg} / \mathrm{cow}$ per day; $P<0.05)$ and milk lactose yield $(0.04 \mathrm{~kg} / \mathrm{cow}$ per day; $P<0.05)$ after 33 wk and lower yields of milk fat $(0.06 \mathrm{~kg} / \mathrm{cow}$ per day; $P<0.05)$ and milk protein $(0.04 \mathrm{~kg} / \mathrm{cow}$ per day; $P<$ $0.05)$ after $36 \mathrm{wk}$ of lactation in pregnant cows. After 36 wk, pregnant cows also secreted less $(P<0.001)$ energy in milk (1.0 Mcal/cow per day).

Fitted splines (Figure 2) showed a significant interaction between pregnancy status and stage of gestation in the concentration of fat $(P<0.01)$ and lactose $(P<$ 
Table 1. Daily milk production in pregnant and nonpregnant twin cows during each third of lactation (wk 1 to 12,13 to 15 and 26 to 38), during the period of lactation when one twin was pregnant (wk 12 to 38 ) and during the breeding season (wk 12 to 17).

\begin{tabular}{llclllc}
\hline & & Milk $^{1}$ & Fat $^{1}$ & Protein $^{1}$ & Lactose $^{1}$ & Milk Energy $^{2}$ \\
\hline Wk 1 to 12 & Pregnant & 18.4 & 0.85 & 0.65 & 0.93 & 23.6 \\
& Not Pregnant & 18.3 & 0.85 & 0.64 & 0.92 & 23.5 \\
& SED $^{3}$ & 0.27 & 0.01 & 0.01 & 0.01 & 0.33 \\
Wk 13 to 25 & $P$ & 0.82 & 0.82 & 0.71 & 0.77 & 0.77 \\
& Pregnant & 15.1 & 0.69 & 0.53 & 0.75 & 19.1 \\
& Not Pregnant & 14.8 & 0.68 & 0.52 & 0.74 & 18.8 \\
& SED $^{3}$ & 0.18 & 0.01 & 0.01 & 0.01 & 0.22 \\
Wk 26 to 38 & $P$ & 0.13 & 0.34 & 0.05 & 0.16 & 0.17 \\
& Pregnant & 10.2 & 0.51 & 0.37 & 0.50 & 13.7 \\
& Not Pregnant & 10.2 & 0.51 & 0.37 & 0.50 & 13.6 \\
& SED $^{3}$ & 0.21 & 0.01 & 0.01 & 0.01 & 0.25 \\
Wk 13 to 38 & $P$ & 0.73 & 0.55 & 0.63 & 0.84 & 0.62 \\
& Pregnant & 13.1 & 0.62 & 0.47 & 0.65 & 17.0 \\
& Not Pregnant & 13.0 & 0.61 & 0.46 & 0.64 & 16.7 \\
& SED & 0.16 & 0.01 & 0.01 & 0.01 & 0.20 \\
Wk 12 to 17 & $P$ & 0.35 & 0.28 & 0.06 & 0.26 & 0.19 \\
& Pregnant $^{3}$ & 17.6 & 0.78 & 0.62 & 0.88 & 22.1 \\
& Not Pregnant $^{3}$ & 17.3 & 0.77 & 0.60 & 0.87 & 21.6 \\
& SED $^{3}$ & 0.23 & 0.01 & 0.01 & 0.01 & 0.28 \\
& $P$ & 0.11 & 0.20 & 0.02 & 0.17 & 0.11 \\
\hline
\end{tabular}

${ }^{1} \mathrm{~kg} /$ cow.

${ }^{2} \mathrm{Mcal} / \mathrm{cow}$.

${ }^{3}$ Standard error of the difference.
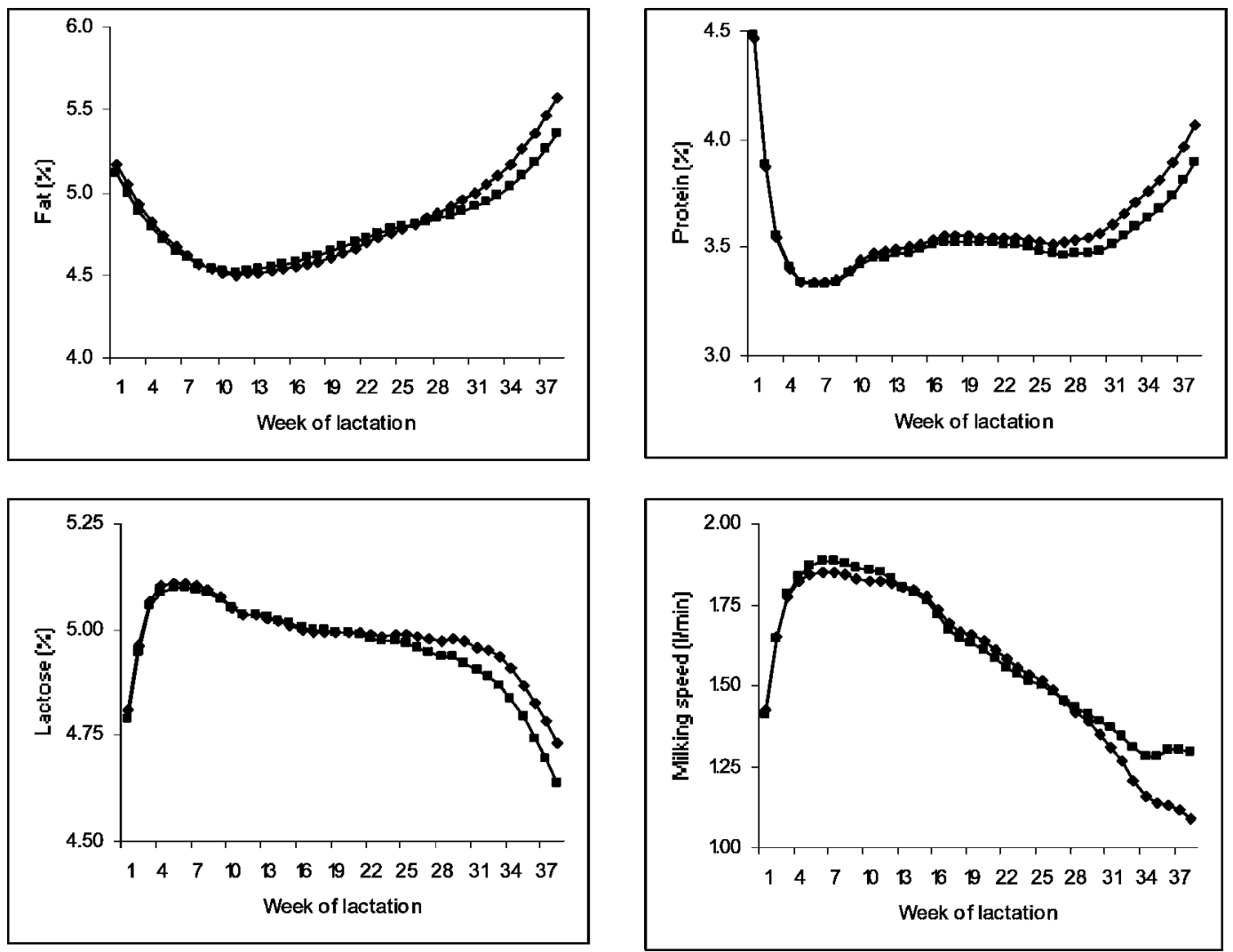

Figure 2.Fitted splines showing the interaction between pregnancy status and stage of gestation in milk composition and milking speed of pregnant ( ) and nonpregnant ( $\mathbf{\square})$ twin cows throughout lactation. 
$0.05)$ in milk, revealing an increased milk fat and lactose concentration in pregnant cows after 30 and $27 \mathrm{wk}$, respectively. The difference in milk fat concentration between pregnant and nonpregnant cows increased from 0.07 percentage units at $30 \mathrm{wk}$, to 0.36 percentage units at the end of lactation ( $38 \mathrm{wk}$ ). Similarly, the difference in milk lactose concentration increased from 0.02 percentage units at $27 \mathrm{wk}$ of lactation to 0.12 percentage units at the end of lactation. Fitted splines did not show an interaction between pregnancy status and stage of gestation in the shape of the lactation curve of milk protein concentration, but protein concentration in the milk of pregnant cows was consistently higher (0.05 percentage units; $P<0.001$ ) than milk from nonpregnant cows. In particular, the concentration of milk protein from pregnant cows was significantly higher from wk 24 to the end of lactation (0.06 and 0.16 percentage units from 24 to $32 \mathrm{wk}$ and 33 to $38 \mathrm{wk}$, respectively; $P<0.05$ and 0.001 , respectively).

During the breeding season (12 to 17 wk of lactation), cows that became pregnant had 0.05 percentage units higher $(P<0.01)$ milk protein concentration and a 0.02 $\mathrm{kg} / \mathrm{cow}$ per day higher milk protein yield $(P<0.05)$ than their nonpregnant twins. Similarly, there was a trend $(P<0.1)$ towards a $0.3 \mathrm{~kg} / \mathrm{cow}$ per day greater milk yield and a greater output of energy in the milk ( 0.46 $\mathrm{Mcal} / \mathrm{cow}$ per day) from cows that became pregnant during the breeding season. A trend towards increased fat and lactose yields in cows that became pregnant was also observed and was significant on individual weeks during the breeding season but not over the entire breeding season.

Fitted splines (Figure 1) showed an increase $(P<$ 0.01 ) in BW in pregnant cows as gestation progressed, and this difference was evident as early as $25 \mathrm{wk}$ in lactation $(5.2 \mathrm{~kg} ; P<0.05)$ and increased linearly $(P<$ 0.01 ) until the end of lactation ( $38 \mathrm{wk})$, when the difference between pregnant and nonpregnant cows was 15.5 $\mathrm{kg}(P<0.001)$. The SCC was not affected by pregnancy status, but the speed of milk flow was reduced $(0.2$ $\mathrm{kg} / \mathrm{min} ; P<0.01$ ) in pregnant cows from 32 to $38 \mathrm{wk}$ of lactation.

\section{DISCUSSION}

The difference in BW between pregnant and nonpregnant cows by the end of 38-wk lactations was $15.5 \mathrm{~kg}$. Although accurate birthweights of calves were not available, herd mates of similar size and genotype produced calves with a mean birthweight of $38 \mathrm{~kg}$. With the equations outlined by Bell et al. (1995) to calculate the weight of the gravid uterus, but scaling down birthweight by $18 \%$ to account for the lower birthweight of the calves in this study, the weight of the gravid uterus in pregnant cows at $182 \mathrm{~d}$ of gestation was calculated to be $15.6 \mathrm{~kg}$. Assuming no difference in BCS between twins, this BW difference suggests we can assume 38 wk of lactation to be equivalent to d 182 of pregnancy in this study. This also implies a mean start of pregnancy of $84 \mathrm{~d}$ (12 wk) in lactation.

Following analysis of DHI data, Bormann et al. (2002) reported higher milk yields and higher yields of milk fat and milk protein in pregnant cows from approximately d 5 to 90 of gestation compared with nonpregnant cows. However, the significance of the difference was not reported. Although milk protein yield was also greater $(0.01 \mathrm{~kg} / \mathrm{cow}$ per day; $P<0.05)$ in pregnant cows in the study reported here and there was a consistent trend $(0.3 \mathrm{~kg} / \mathrm{cow}$ per day; $P=0.13)$ towards higher milk yield in pregnant cows before 25 wk of lactation ( $\sim 90 \mathrm{~d}$ of pregnancy), the difference in milk production was small (Table 1).

Very few studies have examined the effect of pregnancy on milk yield and milk composition, although the effect of days open on lactation yield has been reported (Funk et al., 1987; Lee et al., 1997). It has largely been assumed that the milk production cost of pregnancy occurs through a combination of increased fetal demands for energy from 190 d of gestation onwards (NRC, 2001), and a hormonally mediated partitioning of nutrients away from milk production (Oltenacu et al., 1980). Bell et al. (1995) defined the energy requirements of the gravid uterus from $190 \mathrm{~d}$ of gestation, and NRC (2001) proposed that the energy cost of the gravid uterus before $190 \mathrm{~d}$ is negligible. Eley et al. (1978) and Prior and Laster (1979) reported an exponential growth of fetal tissues, with growth rapidly increasing after $90 \mathrm{~d}$ of gestation (approximately $25 \mathrm{wk}$ of lactation in seasonal herds). This growth of fetal tissue corresponds to the increased BW $(5.2 \mathrm{~kg})$ of the pregnant twin cows after 25 wk of lactation in the present study. From DHI data, Bormann et al. (2002) reported a negative effect of pregnancy on milk volume after approximately $90 \mathrm{~d}$ of gestation. However, the statistical significance of this difference or the point at which the difference became significant were not reported. In the study reported here, the negative effect of pregnancy on milk yield did not become significant until 33 wk of lactation ( 147 d of gestation), even though milk yield was consistently lower in pregnant cows after 30 wk of lactation $(\sim 126$ d of pregnancy in seasonal herds). Higher concentrations of milk protein after $24 \mathrm{wk}$, milk lactose after 27 wk, and milk fat after 31 wk of lactation in pregnant cows when differences in the yield of these constituents was not evident until 36, 33, and 36 wk of lactation, respectively, suggests a pregnancy-derived reduction in milk volume earlier than 33 wk. Even so, expenditure of energy in milk did not increase until $36 \mathrm{wk}$, because 
yields of fat or protein were not affected by pregnancy until this time. It is possible that the hormonal changes resulting in the rapid growth of the fetus after $90 \mathrm{~d}$ also negatively affects milk yield after $90 \mathrm{~d}$ of gestation as results presented by Bormann et al. (2002) suggest, but based on the twin comparison this effect is very small $(<0.04 \mathrm{~kg})$ until $147 \mathrm{~d}$ of gestation.

Total milk production was not affected by pregnancy in the present study $(P=0.35)$. However, if differences in milk production occur late in lactation and lactation length is short, as it was in this study, the difference may be too small to be statistically significant over the entire lactation. The negative effect of pregnancy on the production of milk did occur late in lactation in this study and may be the reason why a significant difference, other than milk protein, was not found when the lactation was considered as a whole.

The reduction in milk production in late lactation in the present study is smaller than that reported by Lee et al. (1997). Lee et al. (1997) reported that pregnant cows produced $9.8 \mathrm{~kg}$ less fat and $9.2 \mathrm{~kg}$ less protein than nonpregnant cows over 305-d lactation, having removed the effect of early lactation (first $100 \mathrm{~d}$ ) milk yield. In comparison, the twin cows in this study produced $1.3 \mathrm{~kg}$ less fat and $0.8 \mathrm{~kg}$ less protein between $\mathrm{d}$ 252 and 266 of lactation.

It is difficult to determine why the results in the present study are so much smaller than those reported by Lee et al. (1997). The main difference between the two data sets is the additional $39 \mathrm{~d}$ of lactation in the report of Lee et al. (1997). Bell et al. (1995) reported a quadratic increase in fetal energy content, with energy deposition increasing by $10 \%$ from 190 to $210 \mathrm{~d}$ of gestation and in each subsequent 20-d period. Assuming a $10 \%$ increase in fetal energy deposition results in a further $10 \%$ reduction in maternal milk energy output and assuming a $10 \%$ increase in fetal energy deposition between 170 and $190 \mathrm{~d}$ of gestation also, 305-d fat and protein yields would be expected to decline by 4.7 and $3.1 \mathrm{~kg}$, respectively, in the present study.

An additional difference between the two studies is the size of the calf. The calves in this study were probably smaller than in the studies reported by Lee et al. (1997) and Bormann et al. (2002). An average calf birthweight of $46 \mathrm{~kg}$ in the United States (Bell et al., 1995), would increase the energy demand of the fetus by $18 \%$. This would result in a pregnancy-induced reduction in milk fat and protein of 5.6 and $3.7 \mathrm{~kg}$, respectively.

Furthermore, pregnant cows in this study and in the report of Bormann et al. (2002) were found to have higher milk yields early in lactation. Therefore, the use of early-lactation milk yields, by Lee et al. (1997), to correct for the lower fertility of high yielding cows may also have a reducing effect on the milk yield of the pregnant cows in later lactation. This may have resulted in a greater difference in milk production, between pregnant and nonpregnant cows, than actually exists.

It is not possible to calculate with certainty, from the current study, the effect of pregnancy on 305-d milk production, as it is unclear what effects hormonal differences would have on milk production, and it is likely that these effects would be greater in higher yielding cows than lower yielding. However, from the present data and the data reported by Lee et al. (1997) and Bormann et al. (2002), it is clear that pregnancy reduces milk production in late lactation (after $168 \mathrm{~d}$ of gestation or $252 \mathrm{~d}$ of lactation in seasonal calving systems) and it is likely that the reduction is between 5.6 and $9.8 \mathrm{~kg}$ milk fat/cow and 3.7 and $9.2 \mathrm{~kg}$ milk protein/ cow over a 305-d lactation. The average lactation length in the seasonal calving, pasture-based systems in New Zealand is $246 \mathrm{~d}$ (Dexcel, unpublished data). In such a system, a pregnancy-induced reduction in milk production is unlikely.

The reduced milk yield results reported by Bormann et al. (2002) after $90 \mathrm{~d}$ of pregnancy appear to be in conflict with the fetal growth data of Bell et al. (1995) with regards to the timing of fetal energy demands. However, Bormann et al. (2002) did not report when the effect of pregnancy on milk constituents became significant. The results reported in the present study show no effect of pregnancy on milk energy output until at least $168 \mathrm{~d}$ of pregnancy (36 wk of lactation), even though milk yield differences may occur earlier. This suggests that the proposed requirements for fetal growth in NRC (2001) are much closer to being correct than the results of Bormann et al. (2002) might suggest. Nevertheless, the reduction in milk component yield in pregnant cows in the present study indicates that pregnant cows reduced the output of energy in milk $\left(\mathrm{NE}_{\mathrm{L}}\right)$ from $0.05 \mathrm{Mcal} / \mathrm{cow}$ per day at $147 \mathrm{~d}$ to $1.25 \mathrm{Mcal} /$ cow per day at $180 \mathrm{~d}$ of gestation. The reduction in energy supply to the mammary gland may be hormonally mediated and may not reflect an energy demand of the fetus (Oltenacu et al., 1980). However, further research is required to more fully understand fetal demands and the effect of pregnancy between 90 to 190 d of gestation.

A major survey in Australia identifying on-farm factors associated with reproductive success reported that cows with a higher milk protein percentage for the first $17 \mathrm{wk}$ of lactation were more likely to be submitted for insemination and more likely to get back in calf (Morton, 2000). For example, cows with a milk protein concentration of $3.5 \%$ during the first $17 \mathrm{wk}$ of lactation had an 8-percentage-unit higher submission rate in 3 
wk and a 20-percentage-unit higher pregnancy rate after 6 wk of breeding compared with cows with a milk protein concentration of $3.0 \%$. This is consistent with the results of the present study, which indicated that cows that became pregnant had a higher milk protein content during wk 12 to 17 of lactation. Morton (2000) surmised that the correlation between fertility and milk protein concentration was associated with the nutritional status of the cow; improved nutritional status results in higher milk protein concentration, and improved fertility. Morton (2000) proceeded to recommend strategies that improve DMI and BCS, presuming that these were the most likely factors related to nutrition that affect both fertility and milk protein concentration. However, the twin cows in the present study were grazed together with the same nutritional inputs and had a very similar BW and, hence, presumably BCS at the start of lactation and during the breeding season.

The reason why one half of a twin pair that achieved a successful pregnancy should have a non-nutritionally related milk protein concentration higher than the nonpregnant twin is unclear. The consistently higher milk protein concentration in the milk of pregnant cows and the lack of a significant difference in the shape of the fitted spline for milk protein concentration suggests that some factor influencing milk protein production also possibly influences fertility. Although not possible to determine from the present study, it is plausible that this factor is of an endocrine nature. Bauman et al. (1988) demonstrated increased mobilization of body tissue and increased milk production in cows supplemented with bST, probably as a result of increased IGF-1 production (Bauman and Vernon, 1993). Higher concentrations of IGF-1 have also been reported to stimulate ovarian function by acting synergistically with gonadotropins to promote growth and steroidogenesis of ovarian cells (Lucy, 2000). The increased concentration and yield of milk protein, the trend towards higher milk fat and lactose yield, and the reduced BW in cows that became pregnant supports a hypothesis of a greater production or activity of IGF-1 in cows that become pregnant. The reason why IGF-1 concentration would increase in one twin but not another within a twin pair remains unclear.

\section{CONCLUSIONS}

A pregnancy-related increase in BW was evident from around $25 \mathrm{wk}$ of lactation or approximately $90 \mathrm{~d}$ of pregnancy. Pregnancy-related reductions in the yield of milk fat and protein occurred after 36 wk of lactation (approximately $168 \mathrm{~d}$ of pregnancy). However, in sea- sonal calving systems the overall cost of pregnancy on milk production is small $(1.3 \mathrm{~kg}$ of milk fat and $0.8 \mathrm{~kg}$ of protein per cow).

Milk protein concentration and yield were actually higher during the breeding season in cows that achieve successful pregnancy. The reason for this association requires further research, in particular examining the role of endocrine factors such as IGF-1.

\section{ACKNOWLEDGEMENT}

The author acknowledges the data collation contributions made by Mr. Peter Copeman and Mr. Alan Napper and the statistical expertise of Ms. Barbara Dow.

\section{REFERENCES}

Bauman, D. E., C. J. Peel, W. D. Steinhour, P. J. Reynolds, H. F. Tyrrell, A. C. G Brown, and G. L. Haaland. 1988. Effects of bovine somatotropin on metabolism of lactating dairy cows: influence on rates of irreversible loss and oxidation of glucose and nonesterified fatty acids. Amer. Inst. Nutr. 1031-1040.

Bauman, D. E. and R. G. Vernon. 1993. Effects of exogenous bovine somatotropin on lactation. Annu. Rev. Nutr. 13:437-461.

Bell, A. W., R. Slepetis, and R. A. Ehrhardt. 1995. Growth and accretion of energy and protein in the gravid uterus during late pregnancy in Holstein cows. J. Dairy. Sci. 78:1954-1961.

Bormann, J., G. R. Wiggans, T. Druet, and N. Gengler. 2002. Estimating effects of permanent environment, lactation stage, age, and pregnancy on test-day yield. J. Dairy Sci. 85(Jan.). Online Available: http://www.adsa.org/jds/.

Eley, R. M., W. W. Thatcher, W. B. Fuller, C. J. Wilcox, R. B. Becker, H. H. Head and R. W. Adkinson. 1978. Development of the conceptus in the bovine. J. Dairy Sci. 61:467-473.

Funk, D. A., A. E. Freeman, and P. J. Berger. 1987. Effects of previous days open, previous days dry, and present days open on lactation yield. J. Dairy Sci. 70:2366-2373.

Genstat VI Committee 2002. Genstat 6, Release 6.1, Reference Manual. Oxford Univ. Press, Oxford, United Kingdom.

Lee, J. K., P. M. VanRaden, H. D. Norman, G. R. Wiggans and T. R. Meinert. 1997. Relationship of yield during early lactation and days open during current lactation with 305 d yield. J. Dairy Sci. 80:771-776.

Lucy, M. A. 2000. Regulation of ovarian follicular growth by somatotropin and insulin-like growth factors in cattle. J. Dairy Sci. 83:1635:1647.

Macdonald, K. 1997. Profitable Dairying. Occasional Publication, New Zealand Rural Press, Ltd., Auckland, New Zealand.

Morton, J. 2000. The Incalf Project. Progress Report No.2. Dairy Research and Development Corp., Victoria, Australia.

National Research Council. 2001. Nutrient requirements of dairy cattle. Subcommittee on Dairy Cattle Nutrition. 7th ed. Publ. Natl. Acad. Press, Washington, DC.

Oltenacu, P. A., T. R. Rounsville, R. A. Milligan, and R. L. Lintz. 1980. Relationship between days open and cumulative milk yield at various intervals from parturition for high- and low-producing cows. J. Dairy Sci. 63:1317-1327.

Prior, R. L and D. B. Laster 1979. Development of the bovine fetus. J. Dairy Sci. 48:1546-1553.

Verbyla, A. P., B. R. Cullis, M. G. Kenward, and S. J. Welham. 1999. The analysis of designed experiments and longitudinal data by using smoothing splines (with discussion). Appl. Stat. 48:269311. 